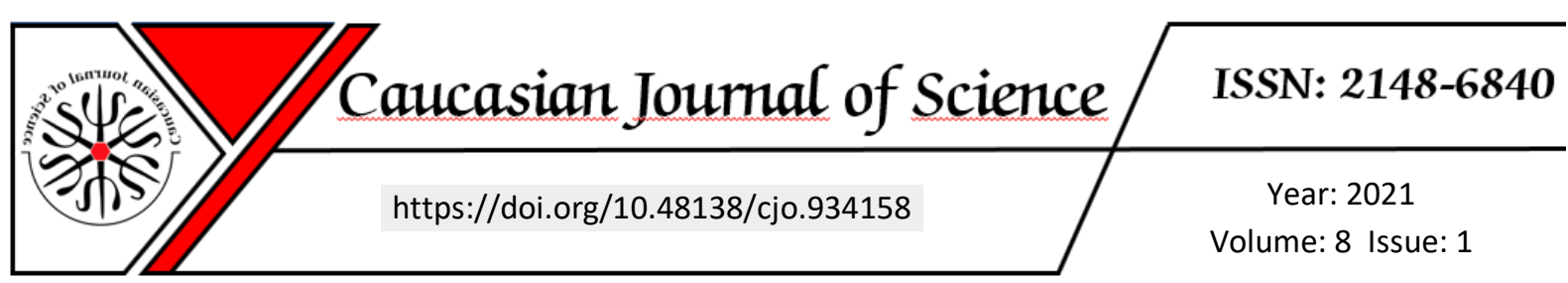

\title{
Physiological and Anti-obesity Effects of Melatonin and Niacin Supplements in Rat Models
}

\author{
Adem KESKIN ${ }^{1}$, Recai ACI ${ }^{2}$, Utku DURAN ${ }^{3}$, Serkan SUGEÇTI ${ }^{4}$
}

Makalenin Alanı: Biyoloji

\begin{tabular}{|c|c|}
\hline Makale Bilgileri & Özet \\
\hline Geliş Tarihi & \multirow{9}{*}{$\begin{array}{l}\text { Son yıllarda dünyada obezitenin artması obezite ile mücadelede yeni stratejilerin } \\
\text { geliştirilmesine yol açmışır. Bu çalışmada, model organizma olarak ratlarda obezite ile } \\
\text { mücadelede niasin ve melatonin takviyelerinin etkisinin araştırııası amaçlanmıştır. } \\
\text { Ratlara } 10 \text { gün süreyle niasin ve melatonin takviyesi yapıldıktan sonra koşu bandı } \\
\text { egzersizi yapııldı. Her grupta } 10 \text { günlük egzersiz sonunda kilo kaybı gözlendi. Bu } \\
\text { çalışmada, koşu bandı egzersizi yapan ratlarda kontrol grubuna göre niasin takviyesinin } \\
\text { kilo kaybına yol açtığı gözlendi. Ayrıca melatonin+niasin takviyesinde gözlenen kilo } \\
\text { kaybının sadece niasin takviyesine göre daha yüksek olduğu bulunmuştur. Sonuç olarak } \\
\text { obezite ile mücadele için egzersiz öncesi niasin ve melatonin takviyesi önerilebilir. }\end{array}$} \\
\hline 07.0 & \\
\hline Kabul Ta & \\
\hline 22.06 .2021 & \\
\hline & \\
\hline Beslenme & \\
\hline Melatonin & \\
\hline & \\
\hline & \\
\hline
\end{tabular}

\begin{tabular}{|c|c|}
\hline Article Info & Abstract \\
\hline Received & \multirow{10}{*}{$\begin{array}{l}\text { In recent years, the increase in obesity in the world has led to the development of new } \\
\text { strategies in combating obesity. In the present study, it was aimed to investigate the } \\
\text { effect of niacin and melatonin supplements to combat obesity in rats as a model } \\
\text { organism. Treadmill exercise was performed on rats after niacin and melatonin } \\
\text { supplementation for } 10 \text { days. In each group, weight loss was observed at the end of the } \\
10 \text { days exercise. In this study, it was observed that niacin supplementation leading to } \\
\text { weight loss in rats that had treadmill exercise when compared to the control group. In } \\
\text { addition, it was found that the weight loss observed in melatonin+niacin supplement } \\
\text { was higher than niacin supplement only. As a result, niacin and melatonin } \\
\text { supplementation can be recommended before exercise to combat obesity. }\end{array}$} \\
\hline 07.05 .2021 & \\
\hline Accepted & \\
\hline 22.06 .2021 & \\
\hline Keywords & \\
\hline Exercise & \\
\hline Nutrition & \\
\hline Melatonin & \\
\hline Niacin & \\
\hline Obesity & \\
\hline
\end{tabular}

\section{INTRODUCTION}

Obesity is a global health problem that affects individuals of all ages, gender, ethnic origin, race, and socioeconomic status. In the US alone, about two-thirds of the adult population is overweight, and about a third of those overweight are considered obese, according to the Centers for Disease Control (Ward et al., 2016). The estimated annual cost of

\footnotetext{
${ }^{1}$ Adnan Menderes University Institute of Health Sciences Department of Medicine Biochemistry-Aydın; e-mail: ademkeskin78@gmail.com; ORCID: 0000-0003-1921-2583 (Sorumlu Yazar)

${ }^{2}$ Samsun Training and Educational Hospital, Biochemistry Department-Samsun e-mail: recaiaci35@gmail.com; ORCID: 0000-0002-3332-6619

${ }^{3}$ Zonguldak Bulent Ecevit University, Çaycuma Food, and Agriculture Vocational School, Department of Veterinary Medicine-Zonguldak email: utku.duran@beun.edu.tr; ORCID: 0000-0002-0002-8893

${ }^{4}$ Zonguldak Bulent Ecevit University, Çaycuma Food, and Agriculture Vocational School, Department of Veterinary Medicine-Zonguldak email: serkan.sugecti@hotmail.com; ORCID: 0000-0003-3412-2367
} 
medical management of obesity-related diseases in the US is more than $\$ 200$ billion (Cawley \& Meyerhoefer, 2012). The latest guideline published by the American Heart Association and the American College of Cardiology for the management of overweight and obesity in adults recommends weight loss at 3-5\% of baseline body weight to lead to a clinically significant reduction in the risk of developing obesity (Jensen et al., 2014). A common strategy for achieving weight loss; to create a negative energy balance by decreasing energy intake and increasing energy expenditure (Spiegelman \& Flier, 2001).

Obesity is associated with an increased prevalence of major health problems, including cardiovascular (CV) disease, diabetes mellitus (DM), and hypertension (Brown et al., 2000; Wormser et al., 2011), and an increased risk of CV mortality (Borrell \& Samuel, 2014) and DM (Wilson et al., 2007; Sasai et al., 2010). It has emerged as a strategy with high potential to improve outcomes in obesity treatment with regular exercise. A reduction in body weight of as much as $5 \%$ provides clinically significant improvements in markers of metabolic health while reducing health risks and mortality with the disease (Magkos et al., 2016)

Niacin is a precursor to NAD / NADH and NADP + / NADPH (Lopez, 2013). The NAD / $\mathrm{NADH}$ redox pair is known as a regulator of cellular energy metabolism in glycolysis and mitochondrial oxidative phosphorylation ( Ying, 2008; Cantó et al., 2015). In addition, niacin supplementation has been reported to reduce free fatty acids in serum, as well as suppress Very Low Density Lipoprotein (VLDL) production and complexation with triglycerides (Wang et al., 2001). However, it is stated that niacin supplementation increases NAD content and energy expenditure in skeletal muscles of high-fat-fed mice (Cantó et al., 2012).

It is stated that melatonin contributes to obesity control by protecting thermogenic brown adipose tissue (Fernández Vázquez et al., 2018). In addition, Melatonin has been shown to prevent obesity in mice through modulation of the gut microbiota (Xu et al., 2017). It is also stated that Melatonin stimulates the expression of anorexigenic genes and inhibits the expression of orexigenic genes (Montalbano et al., 2018).

The increase of obesity in the world in recent years has led to the development of new strategies in combating obesity. Therefore, in this study, we aimed to investigate the antiobesity effect of niacin and melatonin supplementation together with treadmill exercise as physical activity. 


\section{MATERIAL AND METHOD}

The decision of the ethics committee required to study experimental animals was taken from Aydın Adnan Menderes University (ADU) Animal Experiments Local Ethics Committee Center with the decision number 6453101/2018/039 dated 23/03/2018. Experimental animals were provided from ADU Medical Faculty Experimental Animals Center. Transactions carried out with animals, it was in the Faculty of Medicine Experimental Animal Center. In the study, four groups (40 rats in total) consisting of 10 rats (10 rats were used against the risk of death that may occur during the study) weighing between 380-465 grams were used. Rats were Wistar Albino male, 12-13 weeks old. Rats were kept in cages made of transparent polyester. Standard rat food and tap water were given to the rats during the study. There were no restrictions on feed. Rats were randomly divided into four groups ( $\mathrm{n}=$ 10). Experimental groups were formed as follows.

Group 1: Control group (only exercised),

Group 2: Niacin group (Exercise + Niacin supplement (Orally 360 mg / kg / day Niacin)), Group 3: Melatonin group (Exercise + Melatonin supplement $(5 \mathrm{mg} / \mathrm{kg} / \mathrm{day}$ Melatonin intraperitoneally (i.p))),

Group 4: Melatonin + Niacin group (Exercise + Melatonin + Niacin supplement (Intraperitoneal (i.p) $5 \mathrm{mg} / \mathrm{kg} /$ day Melatonin + Oral $360 \mathrm{mg} / \mathrm{kg} /$ day Niacin))

\section{Exercise protocol}

To adapt the rats to the treadmill and exercise, a gentle tempo jogging was done for 5 minutes a day at a speed of $1 \mathrm{~km} /$ hour for 6 days before the study. The exercise model applied by Gronowska-Senger et al. (2009) was used in rats. According to this model, the rats exercise treadmill jogging at $15 \mathrm{~min} /$ day and $20 \mathrm{~m} / \min (1.2 \mathrm{~km} / \mathrm{h})$ for 10 days without inclination. Dynamic 503 (China) treadmill was used as an exercise device (Gronowska-Senger et al., 2009).

\section{Preparation and administration of the melatonin solution}

Melatonin was supplied from Sigma-Aldrich Company as a powder preparation of $1 \mathrm{~g}$. In the preparation of the melatonin solution, it was prepared based on the solution preparation paragraph on the product information page of the relevant company. The product was preserved in the refrigerator at -20 degrees from receipt until the end of the application. Since the melatonin solution is sensitive to light and oxidized in light, it was protected from light from its preparation as a solution to its application to rats. The daily solution was 
prepared considering the weight of each animal from a total of 20 animals in two groups where melatonin was applied.

A slightly hazy, pale yellow solution of melatonin in ethanol at least $50 \mathrm{mg} / \mathrm{mL}$ was prepared. After melatonin was dissolved in ethanol, it was diluted with the isotonic solution. While determining the dose and the duration of administration; Reiter et al. (2016) were determined based on the previous studies on melatonin applications (Reiter et al., 2016). Each animal was weighed every day 30-45 minutes before exercise, and $5 \mathrm{mg} / \mathrm{kg} / \mathrm{day}$ was administered intraperitoneally (i.p) to groups 3 and 4.

\section{Preparation and administration of niacin solution}

Niacin was supplied from Sigma-Aldrich Company as a $100 \mathrm{~g}$ powder preparation. The daily solution was prepared by considering the weight of each animal from a total of 20 animals in two groups where niacin was administered. The solution was prepared by dissolving niacin in distilled water. Solution dosage determination; It was determined based on the study of Kwon et al. (Kwon et al., 2018).

Each animal was weighed every day $30-45$ minutes before exercise, and $360 \mathrm{mg} / \mathrm{kg} / \mathrm{day}$ niacin supplement was given to groups 2 and 4 by oral gavage. Niacin and melatonin supplement a synergistic effect size was calculated in order to see whether the effect of combined administration. To calculate the effect size, it was also created, new groups.

According to this:

Control group = control 1 (control group versus only melatonin supplement with niacin supplement only)

Niacin group = control 2 (comparison of 2 groups receiving melatonin supplement, control group compared to niacin + melatonin group)

Melatonin group = control 3 (comparison of two groups receiving niacin supplement, control group compared to niacin + melatonin group)

\section{Statistical analysis}

SPSS for Windows 22.0 program was used for statistical analysis. In the study, p values, values below 0.05 were considered statistically significant. Data were evaluated using the Kolmogorov-Smirnov normality test. It was observed that the data conformed to normal distribution. The weight results of the body weights of the rats in each group on the first and last days of exercise were tested with the dependent sample t-test. Groups with significant weight loss according to the dependent sample t-test were compared with the independent 
sample t-test. In addition, in order to see that the weight loss observed in the niacin + melatonin group was synergistically significant; Both melatonin-treated groups and niacintreated groups were compared with their control groups by independent sample t-test. Effect sizes were calculated based on the obtained t values and Cohen (1988) and Sawilowsky S (2009) studies (Cohen, 1988; Sawilowsky, 2009).

\section{RESULTS}

In this study, four separate groups were formed. One group received only melatonin, one group only niacin, and one group received both melatonin and niacin supplements. It was formed as a control group in a group. The rats were exercised on the treadmill for 10 days. Weight loss was observed in all groups with 10 days of exercise (Figure 1).

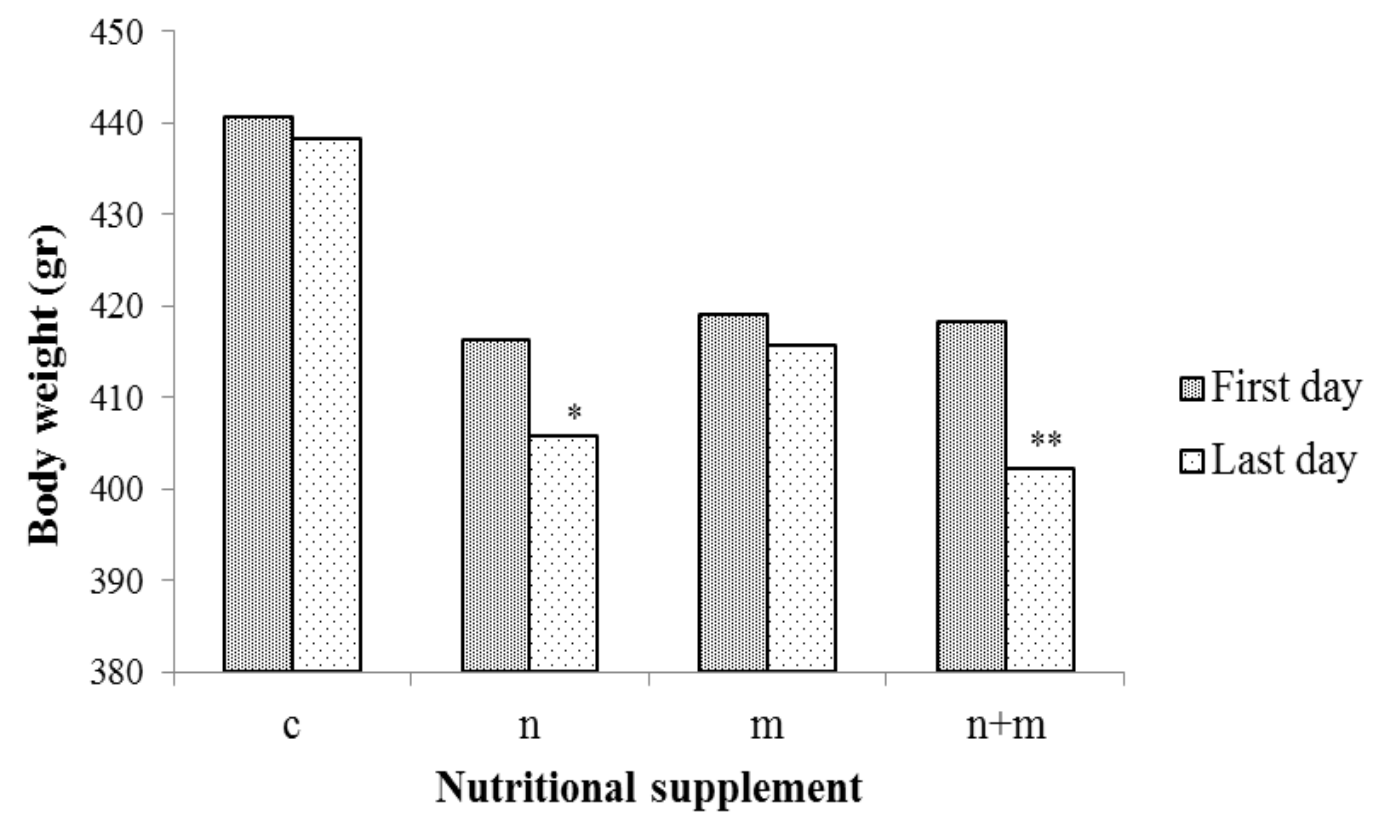

Figure 1. First and last day average body weight values of all groups (gr) (c: control, n: niacin, $\mathrm{m}$ : melatonin, $\mathrm{n}+\mathrm{m}$ : niacin + melatonin group) $(*, * *: \mathrm{p}<0.001)$

This weight loss observed in each group was tested with the dependent sample ttest. Considering the total body weight, this weight loss during exercise was found to be significant in the group that received niacin supplement only and the group in which niacin + melatonin supplements were given together $(p<0.001)$ (table 1$)$. 
Table 1. Dependent sample $t$ test results of weight loss in the study

\begin{tabular}{lcccc}
\hline & Control & Niacin & Melatonin & Niacin+melatonin \\
\hline First day av. (gr) & 440.70 & 416.40 & 419.00 & 418.30 \\
Last day av. (gr) & 438.40 & 405.90 & 415.70 & 402.30 \\
Difference (gr) & 2.30 & 10.50 & 3.30 & 16.00 \\
$\mathbf{t}$ & 1.380 & 7.070 & 2.170 & 11.853 \\
$\mathbf{p}$ (sig.) & 0.201 & $<0.001$ & 0.058 & $<0.001$ \\
\hline
\end{tabular}

The difference between the weight loss observed in these two groups was tested by independent sample t-test. It was determined that the weight loss observed in the group in which niacin + melatonin supplements were given together was higher than the weight loss observed in the group given niacin supplement only $(p=0.014)$ (table 2$)$.

Table 2. Comparison of groups with significant weight loss in terms of weight loss

\begin{tabular}{lccc}
\hline Group 1- Group 2 & $\mathbf{t}$ & $\mathbf{p}$ & Effect size \\
\hline Niacin- niacin+ melatonin & -2.741 & 0.014 & 1.226 \\
\hline
\end{tabular}

Melatonin supplemented groups and their own control groups were tested by independent sample t-test. Effect size (d) was calculated with the obtained t values. When the weight loss of the group in which we only gave melatonin was compared with the control 1 group, no difference was observed between them $(p=0.663, d=0.198)$ (table 3$)$. On the other hand, the weight loss caused by the niacin supplement besides the melatonin supplement was found to be statistically significantly higher than the weight loss of the control 2 group who received niacin supplement $(p=0.014, d=1.226$ ) (table 3 ). According to Cohen's study on effect size in 1988, this value is considered to be a large effect size (Cohen, 1988).

Table 3. Comparison of melatonin supplemented groups with control groups

\begin{tabular}{lccc}
\hline Group 1- Group 2 & $\mathbf{t}$ & $\mathbf{p}$ & Effect size \\
\hline Control 1- melatonin & -0.443 & 0.663 & 0.198 \\
Control 2- niacin+ melatonin & -2.741 & 0.014 & 1.226 \\
\hline
\end{tabular}

The niacin supplemented groups and their control groups were tested by independent samples t-test. Effect size (d) was calculated with the obtained t values. The weight loss of the niacin group was found to be statistically significantly higher when compared to the control 1 
group ( $p=0.002, d=1.643$ ) (table 4 ). On the other hand, the weight loss caused by the administration of melatonin supplement with niacin was statistically significantly higher than the weight loss of the control 3 group who received melatonin supplement. $(p<0.001$, $d=2.793$ ) (table 4).

Table 4. Comparison of niacin supplemented groups with control groups

\begin{tabular}{llll}
\hline Group 1- Group 2 & $\mathbf{t}$ & $\mathbf{p}$ & Effect size \\
\hline Control 1- niacin & -3.673 & 0.002 & 1.643 \\
Control 3- niacin+ melatonin & -6.246 & 0.000 & 2.793 \\
\hline
\end{tabular}

The difference between these two effect sizes is greater than "1.20". According to Sawilowsky's study on effect size in 2009 , this value is considered to be a very large effect size (Sawilowsky, 2009).

\section{DISCUSSION AND CONCLUSION}

In recent years, it has been reported in anti-obesity studies that melatonin or niacin applications limit obesity and regulate physiological and metabolic damage due to obesity (Preuss et al., 2004; Cantó et al., 2012; Mostafavi et al., 2017; Heo et al., 2018; Yin et al., 2018; Ye et al., 2019; Xiang et al., 2020; Mendes et al., 2021). However, there is no study evaluating and comparing niacin and melatonin administration on anti-obesity. The results obtained in this study showed that the combination of niacin supplements with exercise or melatoninniacin supplements helped weight loss in rats. It has shown that melatonin supplements do not lead to weight loss when administered alone, but when combined with niacin supplements, it aids more weight loss than applying niacin supplements alone. It is stated that niacin supplementation increases the NAD content and energy expenditure (Cantó et al., 2012). NAD / NADH plays an important role in the regulation of energy metabolism (Wang et al., 2001; Ying, 2008). In this study, regular weight loss in niacin and niacin-melatonin supplements along with exercise may be the result of niacin and melatonin regulating energy and lipid metabolism. In another study, they conducted a study with obese mice induced by a high-fat diet. In this study of Ye et al., it was noted that mice lacking the niacin receptor GPR109A had progressive weight gain and hepatic fat accumulation (Ye et al., 2019). Canto et al. (2012) conducted a study with mice supplemented with nicotinamide riboside (a form of 
niacin pyridine-nucleoside) (Cantó et al., 2012). They concluded that this supplement increased cellular NAD + levels in skeletal muscle and brown adipose tissue and prevented weight gain and obesity induced by a high-fat diet. In addition, Xiang et al. (2020) concluded that niacin supplementation could improve lipid profiles for patients with T2DM without affecting glycemic levels (Xiang et al., 2020). In addition, Preuss et al. (2004) state that the combination of niacin-bound chromium can be used as a safe weight loss formula (Preuss et al., 2004). Similarly, weight loss was observed in the two groups in which niacin supplement was applied together with exercise in our study.

In this study, it was determined that while melatonin supplementation with regular exercise did not cause weight loss when applied alone, it was determined that it caused weight loss by creating a synergistic effect when applied with niacin. This synergistic effect has been demonstrated as a result of higher weight loss observed in rats administered with melatoninniacin supplements than when niacin or melatonin supplements were administered alone. In addition, a meta-analysis on the role of melatonin on body weight hypothesizes that melatonin has a role as a buffer on body weight changes (Mostafavi et al., 2017). In a study by Heo et al. (2018) with mice, a 10-week oral melatonin supplement ( $100 \mathrm{mg} / \mathrm{kg} / \mathrm{day})$ was given (Heo et al., 2018). It is noted that with this supplement, the body weight gain observed in the obese mouse model induced by a high-fat diet decreased by one third. In the study conducted by Yin et al. (2018) with mice, it is stated that oral melatonin supplementation improves lipid metabolism and reduces lipid accumulation (Yin et al., 2018). On the other hand, in the study conducted by Mendes et al. (2021) in rats, it is stated that melatonin supplementation causes a small weight increase in body mass (Mendes et al., 2021). In the meta-analysis of Mostafavi et al. (2017), the role of melatonin on body weight was investigated (Mostafavi et al., 2017). Seven clinical studies and a total of 244 patients were included in this meta-analysis. As a result, none of the studies included indicated that melatonin had a strong and significant effect on body weight. However, some studies included in this meta-analysis indicated that melatonin had a decreasing or increasing effect on body weight (Mostafavi et al., 2017). Similarly, in our study, weight loss was observed with exercise only in the group given melatonin, but when body weight was taken into account, it was determined that this weight loss had no statistically significant effect. However, when melatonin was applied with niacin, it created a synergistic effect and caused significant weight loss in rats. 
As a result, it was determined that niacin supplementation with exercise has an antiobesity effect. Melatonin + niacin supplementation was found to cause more weight loss in rats than niacin supplementation alone. This study is a pioneering study investigating the antiobesity effects of niacin-melatonin supplementation combined with exercise. In addition, this study is very important in terms of researching anti-obesity factors and physiological strategies against increasing obesity in the world.

Author contributions: $A K$ and RA designed the experiment, performed the experiments and drafted the manuscript. SS and UD contributed to the experimental studies and drafted the manuscript. All authors reviewed and approved the final manuscript.

Conflict of interest disclosure: The authors declare that they have no conflict of interest.

\section{KAYNAKLAR}

Borrell, L. N., \& Samuel, L. (2014). Body mass index categories and mortality risk in US adults: the effect of overweight and obesity on advancing death. American Journal of Public Health, 104(3), 512-519. https://doi.org/10.2105/AJPH.2013.301597

Brown, C. D., Higgins, M., Donato, K. A., Rohde, F. C., Garrison, R., Obarzanek, E., Ernst, N. D., \& Horan, M. (2000). Body mass index and the prevalence of hypertension and dyslipidemia. Obesity Research, 8(9), 605-619. https://doi.org/10.1038/oby.2000.79

Cantó, C., Houtkooper, R. H., Pirinen, E., Youn, D. Y., Oosterveer, M. H., Cen, Y., Fernandez-Marcos, P. J., Yamamoto, H., Andreux, P. A., Cettour-Rose, P., Gademann, K., Rinsch, C., Schoonjans, K., Sauve, A. A., \& Auwerx, J. (2012). The NAD(+) precursor nicotinamide riboside enhances oxidative metabolism and protects against high-fat diet-induced obesity. Cell Metabolism, 15(6), 838-847. https://doi.org/10.1016/j.cmet.2012.04.022

Cantó, C., Menzies, K. J., \& Auwerx, J. (2015). NAD(+) Metabolism and the Control of Energy Homeostasis: A Balancing Act between Mitochondria and the Nucleus. Cell Metabolism, 22(1), 31-53. https://doi.org/10.1016/j.cmet.2015.05.023

Cawley, J., \& Meyerhoefer, C. (2012). The medical care costs of obesity: an instrumental variables approach. Journal of Health Economics, 31(1), 219-230. https://doi.org/10.1016/j.jhealeco.2011.10.003

Cohen, J. (1988). Statistical power analysis for the behavioral sciences. Academic press.

Fernández Vázquez, G., Reiter, R. J., \& Agil, A. (2018). Melatonin increases brown adipose tissue mass and function in Zücker diabetic fatty rats: implications for obesity control. Journal of Pineal Research, 64(4), e12472. https://doi.org/10.1111/jpi.12472 
Gronowska-Senger, A., Magdalena, G., \& Katarzyna, K. (2009). Tocopherol acetate vs. oxidative stress induced by physical exercise in rats. Pol. J. Food Nutr. Sci., 59(3), 263-269. https://doi.org/10.2165/00128415200510340-00041

Heo, J.-I., Yoon, D. W., Yu, J. H., Kim, N. H., Yoo, H. J., Seo, J. A., Kim, S. G., Choi, K. M., Baik, S. H., Choi, D. S., \& Kim, N. H. (2018). Melatonin improves insulin resistance and hepatic steatosis through attenuation of alpha-2-HS-glycoprotein. Journal of Pineal Research, 65(2), e12493. https://doi.org/10.1111/jpi.12493

Jensen, M. D., Ryan, D. H., Apovian, C. M., Ard, J. D., Comuzzie, A. G., Donato, K. A., Hu, F. B., Hubbard, V. S., Jakicic, J. M., Kushner, R. F., Loria, C. M., Millen, B. E., Nonas, C. A., Pi-Sunyer, F. X., Stevens, J., Stevens, V. J., Wadden, T. A., Wolfe, B. M., \& Yanovski, S. Z. (2014). 2013 AHA/ACC/TOS Guideline for the Management of Overweight and Obesity in Adults. Circulation, 129(25 \suppl $\left.\_2\right), S 102-S 138$. https://doi.org/10.1161/01.cir.0000437739.71477.ee

Kwon, W. Y., Suh, G. J., Kim, K. S., Jung, Y. S., Kim, S. H., Lee, A. R., You, K. M., \& Park, M. J. (2018). Niacin and Selenium Attenuate Brain Injury After Cardiac Arrest in Rats by Up-Regulating DJ-1-Akt Signaling. Critical Care Medicine, 46(8), e788-e796. https://doi.org/10.1097/CCM.0000000000003198

Lopez, J. (2013). Carl A. Burtis, Edward R. Ashwood and David E. Bruns (eds): Tietz Textbook of Clinical Chemistry and Molecular Diagnosis (5th edition). Indian Journal of Clinical Biochemistry, 28(1), 104-105. https://doi.org/10.1007/s12291-012-0287-7

Magkos, F., Fraterrigo, G., Yoshino, J., Luecking, C., Kirbach, K., Kelly, S. C., de Las Fuentes, L., He, S., Okunade, A. L., Patterson, B. W., \& Klein, S. (2016). Effects of Moderate and Subsequent Progressive Weight Loss on Metabolic Function and Adipose Tissue Biology in Humans with Obesity. Cell Metabolism, 23(4), 591601. https://doi.org/10.1016/j.cmet.2016.02.005

Mendes, C., Gomes, G., Belpiede, L. T., do Carmo Buonfiglio, D., Motta-Teixeira, L. C., Amaral, F. G., \& CipollaNeto, J. (2021). The effects of melatonin daily supplementation to aged rats on the ability to withstand cold, thermoregulation and body weight. Life Sciences, 265, 118769.

Montalbano, G., Mania, M., Abbate, F., Navarra, M., Guerrera, M. C., Laura, R., Vega, J. A., Levanti, M., \& Germanà, A. (2018). Melatonin treatment suppresses appetite genes and improves adipose tissue plasticity in diet-induced obese zebrafish. Endocrine, 62(2), 381-393. https://doi.org/10.1007/s12020018-1653-x

Mostafavi, S.-A., Akhondzadeh, S., Reza Mohammadi, M., Keshtkar, A.-A., Hosseini, S., Reza Eshraghian, M., Ahmadi Motlagh, T., Alipour, R., \& Ali Keshavarz, S. (2017). Role of melatonin in body weight: A systematic review and meta-analysis. Current Pharmaceutical Design, 23(23), 3445-3452.

Preuss, H. G., Bagchi, D., Bagchi, M., Rao, C. V. S., Dey, D. K., \& Satyanarayana, S. (2004). Effects of a natural extract of (-)-hydroxycitric acid (HCA-SX) and a combination of HCA-SX plus niacin-bound chromium and Gymnema sylvestre extract on weight loss. Diabetes, Obesity \& Metabolism, 6(3), 171-180. https://doi.org/10.1111/j.1462-8902.2004.00328.x

Reiter, R. J., Mayo, J. C., Tan, D.-X., Sainz, R. M., Alatorre-Jimenez, M., \& Qin, L. (2016). Melatonin as an antioxidant: under promises but over delivers. Journal of Pineal Research, 61(3), 253-278. https://doi.org/10.1111/jpi.12360 
Sasai, H., Sairenchi, T., Iso, H., Irie, F., Otaka, E., Tanaka, K., Ota, H., \& Muto, T. (2010). Relationship between obesity and incident diabetes in middle-aged and older Japanese adults: the Ibaraki Prefectural Health Study. Mayo Clinic Proceedings, 85(1), 36-40. https://doi.org/10.4065/mcp.2009.0230

Sawilowsky, S. S. (2009). Very large and huge effect sizes. Journal of Modern Applied Statistical Methods, 8(2), 597-599. https://doi.org/10.22237/jmasm/1257035100

Spiegelman, B. M., \& Flier, J. S. (2001). Obesity and the regulation of energy balance. Cell, 104(4), 531-543. https://doi.org/10.1016/s0092-8674(01)00240-9

Wang, W., Basinger, A., Neese, R. A., Shane, B., Myong, S.-A., Christiansen, M., \& Hellerstein, M. K. (2001). Effect of nicotinic acid administration on hepatic very low density lipoprotein-triglyceride production. Am. J. Physiol. Endocrinol. Metab., 280(3), E540-E547. https://doi.org/10.1152/ajpendo.2001.280.3.E540

Ward, Z. J., Long, M. W., Resch, S. C., Gortmaker, S. L., Cradock, A. L., Giles, C., Hsiao, A., \& Wang, Y. C. (2016). Redrawing the US Obesity Landscape: Bias-Corrected Estimates of State-Specific Adult Obesity Prevalence. PloS One, 11(3), e0150735. https://doi.org/10.1371/journal.pone.0150735

Wilson, P. W. F., Meigs, J. B., Sullivan, L., Fox, C. S., Nathan, D. M., \& D’Agostino, R. B. S. (2007). Prediction of incident diabetes mellitus in middle-aged adults: the Framingham Offspring Study. Archives of Internal Medicine, 167(10), 1068-1074. https://doi.org/10.1001/archinte.167.10.1068

Wormser, D., Kaptoge, S., Di Angelantonio, E., Wood, A. M., Pennells, L., Thompson, A., Sarwar, N., Kizer, J. R., Lawlor, D. A., Nordestgaard, B. G., Ridker, P., Salomaa, V., Stevens, J., Woodward, M., Sattar, N., Collins, R., Thompson, S. G., Whitlock, G., \& Danesh, J. (2011). Separate and combined associations of bodymass index and abdominal adiposity with cardiovascular disease: collaborative analysis of 58 prospective studies. Lancet (London, England), 377(9771), 1085-1095. https://doi.org/10.1016/S0140$6736(11) 60105-0$

Xiang, D., Zhang, Q., \& Wang, Y.-T. (2020). Effectiveness of niacin supplementation for patients with type 2 diabetes: A meta-analysis of randomized controlled trials. Medicine, 99(29), e21235. https://doi.org/10.1097/MD.0000000000021235

Xu, P., Wang, J., Hong, F., Wang, S., Jin, X., Xue, T., Jia, L., \& Zhai, Y. (2017). Melatonin prevents obesity through modulation of gut microbiota in mice. Journal of Pineal Research, 62(4). https://doi.org/10.1111/jpi.12399

Ye, L., Cao, Z., Lai, X., Wang, W., Guo, Z., Yan, L., Wang, Y., Shi, Y., \& Zhou, N. (2019). Niacin fine-tunes energy homeostasis through canonical GPR109A signaling. The FASEB Journal, 33(4), 4765-4779. https://doi.org/10.1096/fj.201801951R

Yin, J., Li, Y., Han, H., Chen, S., Gao, J., Liu, G., Wu, X., Deng, J., Yu, Q., \& Huang, X. (2018). Melatonin reprogramming of gut microbiota improves lipid dysmetabolism in high-fat diet-fed mice. Journal of Pineal Research, 65(4), e12524.

Ying, W. (2008). NAD+/NADH and NADP+/NADPH in cellular functions and cell death: regulation and biological consequences. Antioxidants \& Redox Signaling, 10(2), 179-206. https://doi.org/10.1089/ars.2007.1672 